\title{
Special international consensus and systematic review issue: hips, tendons, shoulders, knees, backs, Ramadan and coffee!
}

\author{
Karim M Khan
}

What is in this issue of BJSM for you? We usually highlight one or two papers on a cover but we had to include six this time, as the quality was just too high to overlook any! (figure 1). While on the cover ... a shout out to medical artist Vicky Earle (Canada,@EarleArt) on her 12th anniversary as BJSM cover artist. Thank you!

The best and brightest share their consensus with clinicians who treat hip pain and tendon pain. Hip-related painemanating from conditions such as femoroacetabular impingement syndrome (cam lesion in figure 1), acetabular dysplasia or labral tears-carries a very large burden of disease. Over 40 physiotherapists, sport and exercise medicine physicians and other hip-pain experts spent a year preparing for a November (2018) weekend of vigorous discussion in Zurich at the world-famous Schultess Clinic. Check out one of the four Consensus Statements in this issue (see page 631) and kudos to all members of the International Hip-related Pain Research Network. Singling out is always risky but Professor Kay Crossley (La Trobe University, @KayMCrossley) and Dr Mario Bizzini (Swiss Sports Physiotherapy Association (@SportfisioSwiss) had the vision. You can find the three other papers from that meeting here. ${ }^{1-3}$

Thirty representatives of the international clinical tendon science community met for the fifth time in Groningen (Netherlands). ${ }^{4}$ The authors guide us on terminology, ${ }^{5}$ how to report tendon studies (see page 627) as well as steps to developing a new patient-reported outcome measure in the field. ${ }^{6}$

\section{A SPECIAL REVIEW ISSUE OF BJSM- SIX OF THE BEST}

BJSM editors accept an equal number of original data papers and systematic reviews per year. In this issue, we highlight six high-quality reviews and we thank Dr Clare Ardern, now the Editor-in-Chief of the Journal of Orthopaedic and Sports

Correspondence to Dr Karim M Khan, Family Practice \& Kinesiology, The University of British Columbia,

Vancouver, BC V6T 124, Canada; karim.khan@ubc.ca
Physical Therapy (JOSPT, @JOSPT) for her international leadership in raising the bar of sport and exercise medicine systematic reviews as a BJSM deputy-editor from 2015 to 2018.

What are the take home messages? (1) If you are a clinician who sees patients with meniscal injuries, or with shoulder pain (previously known as 'impingement'), our Oxford (see page 652) and Helsinki (see page 665) authors give you good cause to embrace non-surgical quality rehabilitation treatment in the first instance. They don't say surgery never has a role-but the pendulum has definitely swung from the halcyon 1980s and 1990s where the arthroscopic snipper and shaver seemed mightier than the carefully guided exercise programme by a highly-trained, experienced and very smart physiotherapist. The pantheon of authors on those two papers alone includes Professors Rachelle Buchbinder, David Beard and Gordon Guyatt. Further evidence for physiotherapy in patients with knee pain comes via a high-quality RCT proving that exercise was superior to arthroscopic

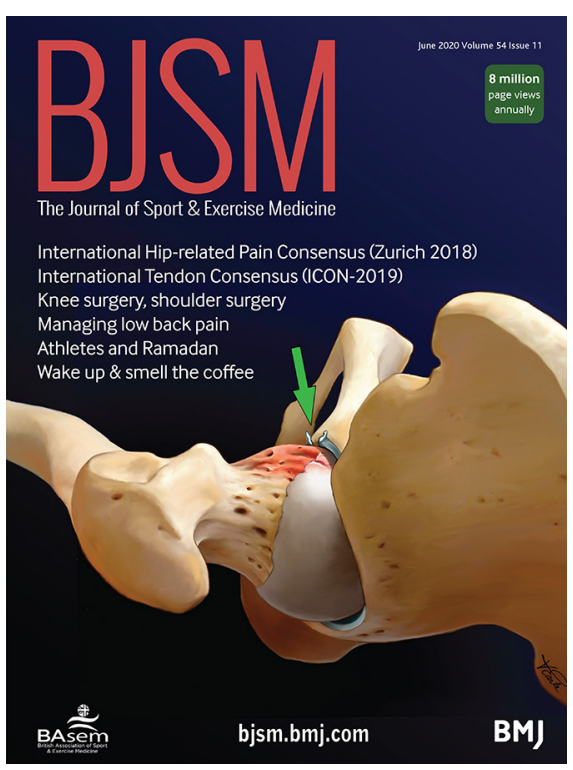

Figure 1 Cam lesion as described in the femoroacetabular impingement-one element of the femoroacetabular (FAI) syndrome. partial meniscectomy, ${ }^{7}$ and the 2020 New England Journal of Medicine paper showing the futility of corticosteroid injection for knee osteoarthritis. ${ }^{8}$

Take home message (2): If you are a clinician who sees patients with back pain, the authors give you good cause to educate and provide exercise therapy. Leaders from our community (sport and musculoskeletal physiotherapy, sport and exercise medicine, pain science) have contributed substantially to advances over the past 20 years. Of concern is the clear, industry-driven (refer to court-case settlements) overhyping of the benefits of opioids and glossing over their addictive nature. Dr Hannah-Rose Tucker apprises you of the harms and benefits of opioids in acute and chronic low back pain (see page 664). Kudos to senior author preeminent physiotherapist polymath Professor Chad Cook (Duke University, @ChadCook PT). Too much investigation is also a problem in the Wealthy West (http:// ow.ly/Z8od50ziGMu)—imaging has been part of that excess. Thanks Aron Downie whose $\mathrm{PhD}$ studies led to imaging reviewing papers that reported over 4 million imaging requests (see page 642).

\section{RAMADAN AND SLEEP: COFFEE AND PERFORMANCE}

Further underscoring BJSM's international perspective, this issue drops during Ramadan which, until this pandemic year, has been accompanied by sporting events. The Olympic Games (2012) and the FIFA World Cup (2018) took place during Ramadan. In this 2020 BJSM Ramadan issue, Dr Khaled Trabelsi from the 1100-year-old city of Sfax (Tunisia) synthesised the evidence on how athletes' sleep alters during this time of spiritual reflection (see page 674).

Also affecting sleep, but not reaching the status of religion, is coffee. Dr Jozo Grgic, denizen of coffee Mecca Melbourne, averaged two lattes per day as he punched out his systematic review of the performance benefits of caffeine. Interestingly, this number-two cups per day-is the much more pleasant equivalent of the tablet dose of caffeine that benefitted a wide range of exercise tasks-both aerobic and anaerobic (see page 681).

Funding The authors have not declared a specific grant for this research from any funding agency in the public, commercial or not-for-profit sectors.

Competing interests None declared.

Patient consent for publication Not required.

Provenance and peer review Commissioned; internally peer reviewed. 
Warm up

(c) Author(s) (or their employer(s)) 2020. No commercial re-use. See rights and permissions. Published by BMJ.

\section{A) Check for updates}

To cite Khan KM. Br J Sports Med 2020;54:625-626.

Accepted 20 April 2020

Br J Sports Med 2020;54:625-626.

doi:10.1136/bjsports-2020-102502

\section{ORCID iD}

Karim M Khan http://orcid.org/0000-0002-9976-0258

\section{REFERENCES}

1 Kemp JL, Risberg MA, Mosler A, et al. Physiotherapistled treatment for young to middle-aged active adults with hip-related pain: consensus recommendations from the International Hip-related pain research network, Zurich 2018. Br I Sports Med 2020;54:504-11.

2 Mosler AB, Kemp J, King M, et al. Standardised measurement of physical capacity in young and middle-aged active adults with hip-related pain: recommendations from the first international Hiprelated pain research network (IHiPRN) meeting, Zurich, 2018. Br I Sports Med 2019:doi: 10.1136 bjsports-2019-101457. [Epub ahead of print 19 Dec 2019]..

3 Impellizzeri FM, Jones DM, Griffin D, et al. PatientReported outcome measures for hip-related pain: a review of the available evidence and a consensus statement from the International Hip-related pain research network, Zurich 2018. Br J Sports Med 2020:doi: 10.1136/bjsports-2019-101456. [Epub ahead of print 17 Feb 2020].

4 Zwerver J, Mc Auliffe S, Rio EK, et al. Icon 2019-international scientific tendinopathy symposium: building an iconic tendon tower-launching a new era in clinical tendinopathy research. $\mathrm{Br}$ J Sports Med 2020;54:442-3.

5 Scott A, Squier K, Alfredson H, et al. Icon 2019: international scientific tendinopathy symposium consensus: clinical terminology. Br I Sports Med 2020:54:260-2.

6 Vicenzino B, de Vos R-J, Alfredson H, et al. Icon 2019-International scientific tendinopathy symposium consensus: there are nine core health-related domains for tendinopathy (core domains): Delphi study of healthcare professionals and patients. Br J Sports Med 2020;54:444-51.

7 Kise NJ, Risberg MA, Stensrud S, et al. Exercise therapy versus arthroscopic partial meniscectomy for degenerative meniscal tear in middle aged patients: randomised controlled trial with two year follow-up. BMJ 2016;354:i3740.

8 Deyle GD, Allen CS, Allison SC, et al. Physical therapy versus glucocorticoid injection for osteoarthritis of the knee. N Engl J Med 2020;382:1420-9. 